IRSH 59 (20I4), Special Issue, pp. 45-68 doi:I0.10I7/So0208590I 4000327 (C) 2014 Internationaal Instituut voor Sociale Geschiedenis

\title{
Getting Away with Murder: The Wrongful Deaths of Lascars Aboard the Union in 1802
}

\author{
JAMES W. FREY \\ Department of History, University of Wisconsin - Oshkosh \\ 800 Algoma Blvd, Oshkosh, WI 5490I, USA \\ E-mail: freyj@uwosh.edu
}

\begin{abstract}
In i 802, several "country ships" arrived in London from Bengal, their lascar crews having suffered severe casualties due to fatigue, exposure, and starvation. Aboard the Union, the officers' treatment of the crew was so bad that the lascars and a sympathetic English sailor alerted the East India Company. Their testimony, recorded by the Company's Committee of Shipping, provides new insights into lascar living and working conditions - in particular the problem of undermanning ships - reminding us how the management-labour dynamic aboard a ship at sea always favoured owners and officers rather than workers.
\end{abstract}

\section{THE “COUNTRY SHIP” UNION}

On 28 February 1802 , the Union reached Gravesend after a five-anda-half-month voyage from Bengal under Captain John Luke. Unlike East Indiamen owned by the East India Company or leased for its Maritime Service, the Union was a "country ship". Its owners, William and Horsley Palmer, were established London shipping investors connected with their family's Calcutta agency house, Palmer \& Company. ${ }^{I}$ The Union was licensed to operate within the Company's exclusive economic zone, carrying non-monopoly cargoes and "gruff goods" for the East India Company. The officers and crews of such privately managed country ships were subject to laws and regulations laid down for and by the Company. ${ }^{2}$

I. Anthony Webster, "The Strategies and Limits of Gentlemanly Capitalism: The London East India Agency Houses, Provincial Commercial Interests, and the Evolution of British Economic Policy in South and South East Asia, I800-50", Economic History Review, New Series, 59 (2006), pp. 743-764.

2. "Governor-General Wellesley to the Court of Directors, 30 September i 800 ", Asiatic annual register, or, A view of the history of Hindustan, and of the politics, commerce and literature of Asia, For the Year I80I (London, I802), pp. 48-61. 
When an official account of the ill-treatment of the Union's mostly Indian or lascar crew was published in the widely circulated Third Report of the Special Committee, Captain Luke wrote to James Coggan, Master-Attendant of Shipping at East India House, defending his actions. The Company's Committee of Enquiries simultaneously investigated various charges brought against Luke and his officers by an aggrieved English sailor and several lascars. The present article is based on the I33-page proceedings of the Committee of Shipping, which regulated both the Company's shipping and licensed private trading vessels operating within the East India Company's monopoly zone.

The Company's investigation of the atrocities aboard the Union is significant because public exposure of these crimes tested the Committee of Shipping's resolve to act in its evolving role as regulator of labour conditions in the east India country trade. The testimony recorded by the Committee offers a glimpse of living and working conditions experienced by lascar crews in the late eighteenth and early nineteenth centuries, shedding light on undermanning, the practical handling of a large sailing ship, and discipline. ${ }^{3}$ Exploration of the Union case also reveals the power dynamics inherent in management-labour relations aboard merchantmen making long voyages in the age of sail. ${ }^{4}$

Although subjected to extreme, often deadly, violence, the Union's crew confronted their officers without resorting to mutiny. The lascars found an ally and advocate in John Moore, an English boatswain's mate, a low-ranking petty officer, who risked his career, and even his life, in trying to stop the assaults and neglect while the ship was at sea. Moore's attempt to organize his Indian shipmates speaks to the dangers and practical difficulties all maritime labourers faced even when legally questioning a captain's authority. Finally, the juxtaposition of the frenzied violence of Luke and his officers with Moore's humane concern and openness to the Union's lascars uncovers the spectrum of attitudes regarding race and culture existing within the microcosm of a single ship.

I begin by situating my study within the framework of existing lascar research. I then consider the problem that first struck the Committee of Shipping - the small number of the Union's crew, given the ship's size. As Moore and his Indian shipmates testified, undermanning was the prime cause of the Union's problems, and such extreme undermanning indicates a callous, unrealistic view of maritime labour. The Union's

3. Gopalan Balachandran, Globalizing Labour? Indian Seafarers and World Shipping, c. I870-1945 (New Delhi, 2012).

4. Even at the beginning of the nineteenth century, "management" was used in its modern sense with regard to shipping, and I here use the term to refer not only to ships' officers, but also owners, bearing in mind that the authority of a ship's officer over subordinates, at sea, was absolute. The term "labour" was used in its modern sense in economic writings of the late eighteenth century, and entered common parlance in the early nineteenth century. 
overworked crew were denied sheltered berths, time off duty, adequate provisions, appropriate clothing, and medical care, all while being terrorized and beaten constantly. The third section of this article examines the crew's testimony and resistance. Fourthly, I examine the opinions of the Company's attorneys, who, although convinced Moore and the Union's lascars were truthful, advised the Committee of Shipping not to charge Luke and his chief mate. In conclusion, I reflect upon the significance of the Union case with respect to the broader context of maritime labour history in the "Global South" during the age of sail.

\section{PERSPECTIVES ON LASCAR LABOUR}

"Lascar" was a term used by Europeans to refer to all Asian sailors, but in the British imagination lascars were usually "natives of India". The hiring of indigenous auxiliaries to complete depleted Western crews and bolster the ranks of dwindling military forces began with the Portuguese in the early sixteenth century. The practice of manning merchant ships with lascars spread and grew with the east India trade during the next two centuries, drawing mariners from nearly every population touched by Western commerce across the Indian Ocean, the archipelago of south-east Asia, and the China Sea.' Most of south Asia's Muslim seafaring communities contributed sailors to the European mercantilist companies, not to mention to a host of private traders. By the early eighteenth century several centres of lascar recruitment had emerged: Kachchh and the Gulf of Khambat, the Konkan, and Malabar - all on India's western coast - and Bengal-Bihar, specifically the districts of Sylhet, Noakhali, and Chittagong. Recruits from the districts around Patna usually worked as stewards and guards, not as second-class lascars (deckhands) or first-class lascars, who were able-bodied seamen working aloft on the masts and rigging. ${ }^{6}$

While some ships' officers were well-versed in Hindustani, most knew only key words and stock phrases. Because of this language barrier, and in conformity with pre-colonial patterns of labour procurement, lascars found work aboard European ships through intermediaries called ghat-serangs. Typically, a ghat-serang supplied an entire crew, embarking them already organized under their own petty officers, the most important being the serang, corresponding to a European boatswain, but also acting as the

5. Michael H. Fisher, "Working across the Seas: Indian Maritime Labourers in India, Britain, and in Between, I600-1857", in Rana P. Behal and Marcel van der Linden (eds), "Coolies, Capital, and Colonialism: Studies in Indian Labour History", International Review of Social History, 5 I (2006), Supplement I4, pp. 2 I-45.

6. Edward Simpson, Muslim Society and the Indian Ocean: The Seafarers of Kachchb (London, 2006); Franklin J.A. Broeze, "The Muscles of Empire - Indian Seamen and the Raj, 1919-1939", Indian Economic and Social History Review, I 8 (1981), pp. 43-67; Michael H. Fisher, Counterflows to Colonialism: Indian Travellers and Settlers in Britain, I600-I857 (New Delhi, 2004), pp. I42-I43. 
ghat-serang's agent, being in charge of the men's pay. The serang was assisted by a number of mates, called tindals, while some lascars, such as "seacunnies", were experienced helmsmen able to take a turn at the ship's wheel, and thus had a status nearly equal to that of a tindal.

Most recent research on lascars has focused on the well-documented period after 1870, when travel and trade between Britain and Asia was dominated by iron-hulled steamships. Steamers transformed shipping, especially in the Indian Ocean, where monsoons no longer dictated when and where ships could sail. Whether rusty tramps or crisply painted $\mathrm{P} \& \mathrm{O}$ passenger ships, steam-driven vessels were safer than sailing ships, especially in stormy weather. However, in the stokehold, where the sea was invisible, the working environment was more industrial than maritime. ${ }^{8}$ Since seafaring skills were no longer in demand, any man could be a lascar. Those with brute strength and spirit enough to stand the long, punishing hours could find work as stokers in the fierce engine-room heat. Agile men with quick hands performed the dangerous task of manually applying lubricant to moving engine parts. Other men laboured aboard the new ships as cooks, stewards, and deckhands. ${ }^{9}$

Studies of the period after I 870 compare the lot of Indian seamen with the slave-like existence of south Asian coolies throughout the British Empire in the era of high imperialism. Like coolies, lascars were contract labourers recruited through middlemen. The very mobility of coolies and mariners trapped them in artificial, isolated settings - ships, plantations, mines, and construction sites - where they were a minority vis-à-vis indigenous populations, dependent on European employers for the necessities of life. Finally, like coolies, lascars had very little bargaining power due to their dependent, vulnerable condition. ${ }^{10}$

As Ravi Ahuja argues, contract labour systems in the late nineteenthand early twentieth-century British Empire were racist institutions, their inequalities justified by appeals to Social Darwinist thinking. Racial categories, enshrined in law, were employed to limit opportunities and suppress

7. Fisher, "Working across the Seas"; Anne Bulley, The Bombay Country Ships, I790-1 833 (Richmond, 2000), pp. 228-239.

8. Jonathan Hyslop, "'Ghostlike' Seafarers and Sailing Ship Nostalgia: The Figure of the Steamship Lascar in the British Imagination, c.I880-1960", paper presented at the Lascars Workshop, University of Southampton, $20 \mathrm{I}$ I.

9. Ravi Ahuja, "Networks of Subordination - Networks of the Subordinated: The Ordered Spaces of South Asian Maritime Labour in an Age of Imperialism (c.1890-1947)", in Ashwini Tambe and Harald Fisher-Tiné (eds), The Limits of British Colonial Control in South Asia: Spaces of Disorder in the Indian Ocean Region (London, 2009), pp. 13-48.

I0. Ravi Ahuja, "Mobility and Containment: The Voyages of South Asian Seamen, c.1900-1960", in Behal and Van der Linden, "Coolies, Capital, and Colonialism”, pp. I I I-I4I; Gopalan Balachandran, "Conflicts in the International Maritime Labour Market: British and Indian Seamen, Employers, and the State, 1890-1939", Indian Economic and Social History Review, 39 (2002), pp. 7 1-99. 
wages for both coolies and lascars. Harder for capitalists, politicians, and not least white labour leaders to justify was the fact that Indian coolies and lascars, despite accusations of chronic weakness and malingering, worked long hours under difficult, even sub-standard conditions, performing work others considered tedious, degrading, or dangerous. Others did not bother with justifications, arguing instead that lascars were easier to manage (i.e. more amenable to exploitation) than British sailors. ${ }^{\text {I }}$

The lascar's world in the age of sail, however, seems different from the later periods in many respects, including the dynamic of racial difference: explicitly articulated in the late nineteenth-century archive, studies of later lascar history help to locate the racism of the pre-industrial lascar system, which must be understood not as crass, outright prejudice, but as a systematic fostering of inequality through dependency. The records of the late eighteenth and early nineteenth centuries were less obsessed with racial difference than those of the Victorian and Edwardian eras, although sometimes imbued with subtle racial tension. Instead of resorting to simplistic, pseudo-scientific arguments regarding racial difference, documents of the period under study in this article focus on perceived physical differences between European sailors and lascars, in particular the notion that Indian sailors could not function in "cold waters". ${ }^{\text {I2 }}$

However, overall, the documents dealing with the Union concern class more than race - class being an idea cutting across ethnic boundaries prior to the 1830 , as Michael Fisher has demonstrated in various publications. The primary "problem" with lascars, for most Britons at the time of the Union disaster, was not that they were Indian, but that they were not gentlemen, or - like ayabs and other Indian servants - clearly part of a gentleman's household. ${ }^{13}$ One of the worries of Company officials was, e.g., that if "ordinary" Indians, like lascars, spent too much time in London with ordinary English men and women, they might carry home tales damaging to the Company's reputation in India. ${ }^{\text {I4 }}$

II. See Ahuja, "Networks of Subordination"; Gopalan Balachandran, "Searching for the Sardar: The State, Pre-Capitalist Institutions, and Human Agency in the Maritime Labour Market, Calcutta, I880-1935", in Burton Stein and Sanjay Subrahmanyam (eds), Institutions and Economic Change in South Asia (Delhi, 1996), pp. 206-236.

I 2. David Macpherson, The History of the European Commerce with India (London, I8I2), p. 235. I3. Michael H. Fisher et al., A South-Asian History of Britain: Four Centuries of Peoples from the Indian Subcontinent (Oxford, 2007), pp. 23-70; Michael H. Fisher, "Excluding and Including 'Natives of India': Early-Nineteenth-Century British-Indian Race Relations in Britain", Comparative Studies of South Asia, Africa and the Middle East, 27 (2007), pp. 30I-3 I4; idem, Counterflows to Colonialism, pp. 8-1 3; Marika Sherwood, "Race, Nationality and Employment among Lascar Seamen, I660-I945”, New Community, I7 (1991), pp. 229-244.

I4. "Report of the Special Committee to Henry Dundas", 27 February i801, Asiatic annual register (1802), pp. 9-40. It is worth noting that this view was not uncontested, even within Company circles. 
A lot of the research on the early period of lascar history (c.1750-I 850 ) concerns the thousands of Indian sailors stranded in London by the antilascar clauses of the Navigation Acts. The work of Rozina Visram positions these early, rather hapless lascar migrants within a larger history of Asians and Indians in Britain, placing them alongside more socially visible or prestigious early "immigrants" - ayahs, envoys, scholars, merchants, princes, and eventually college students. ${ }^{\text {IS }}$ However, recent studies focus less on pioneering and more on the problems and prejudice encountered by lascars. Under late eighteenth-century British law, foreigners became British subjects after serving two years in the Royal Navy, but lascars were never considered British. Necessary but unwanted, possibly dangerous, aliens, lascars were both pitied and reviled. The British government forced the East India Company to take responsibility for all lascars, hospitalizing those who were ill while interning the rest in a barracks administered much like a debtor's prison. Here the lascars remained until they could be repatriated, for the protectionist Navigation Acts made it nearly impossible for them to find berths aboard ships returning to India. ${ }^{16}$

Norma Myers and Shompa Lahiri consider the limbo endured by lascars as part of the making of a non-white British working class. ${ }^{17}$ Michael Fisher builds upon the work of Myers and Lahiri, bringing to it his nuanced understanding of the East India Company and the India from which lascars hailed. The research conducted by Myers, Lahiri, and Fisher uncovers hitherto unknown episodes of lascar resistance to what can only be termed semi-incarceration - resistance that occasionally took the form of rioting. Yet, there was more to the transitory world of the interned lascar than confinement, petty misbehaviour, and protest, as the Company's officials were aware. Lascars formed personal alliances with lower-class British women; they endured poverty and vagrancy; they appeared as victims and accused in criminal trials; and they suffered terribly during the cold winters of the period under study. The Company tried to help Indian sailors, but, as Fisher informs us, its sub-contracted system of lascar internment was exploitative, paternalistic, and - like so many Company endeavours inadequate to the changing scope of a rapidly expanding task. ${ }^{18}$

Myers, Lahiri, and Fisher all mention the Union incident in passing. Indeed, for political purposes, the Committee of Shipping made sure their

I 5. Rozina Visram, Asians in Britain: 400 Years of History (London, 2002); and idem, Ayahs, Lascars and Princes: Indians in Britain, $1700-1947$ (London, 1984).

I6. Fisher, Counterflows to Colonialism, pp. I37-16I.

17. Norma Myers, "The Black Poor of London: Initiatives of Eastern Seamen in the Eighteenth and Nineteenth Centuries", in Diane Frost (ed.), Ethnic Labour and British Imperial Trade: A History of Ethnic Seafarers in the UK (London, 1995), pp. 7-21; Shompa Lahiri, "Contested Relations: The East India Company and Lascars in London”, in H.V. Bowen, Margarette Lincoln, and Nigel Rigby (eds), The Worlds of the East India Company (Woodbridge, 2006), pp. 169-182. I8. Fisher, Counterflows to Colonialism, pp. I37-16I. 
printed description of conditions aboard the ship was widely distributed and reprinted before every debate about the relative merits of country ships and regular East Indiamen - the Union, therefore, is difficult to miss. However, this essay is the first to delve into the primary documents concerning the Union in detail, focusing specifically on lascar living and working conditions, and on management-labour relations aboard the ship. My purpose is to show why lascars often reached London at the point of death, and to critique the longstanding assumption that private shipping in the east India trade was more efficient and therefore "better" than East Indiamen. The private trader's short-sighted quest for rapid return on investment had an extremely high human cost.

\section{THE UNDERMANNING OF COUNTRY SHIPS}

The Committee of Shipping first became aware of the poor health of the Union's lascars on 24 March i 802, twenty-five days after the ship's arrival at Gravesend. On that date, after visiting the ship, William Docker, the Company's Medical Superintendent for Lascars, wrote:

[Nine] sick Lascars were ordered from on board the Union [...]. As they were removing them $[\ldots]$ one died - the rest appeared $[\ldots]$ exceedingly ill: three of these are dead. I waited on the captain to inform him in what manner the East India Company's men were attended, and offered my service to those on board. His answer was they were all well; and when any were taken ill, they should be sent on shore. I understand most of them were ill [...]. ${ }^{19}$

As soon as the Union sailed up the Thames to London, its serang, Mir Jahan, was summoned to East India House. According to the serang, the Union's crew initially consisted of fifty-five lascars and seven "sepoys" signed on at Calcutta. ${ }^{20}$ Eight lascars were transferred aboard from the Suffolk, Luke's previous command, while both ships were anchored at Saugor, bringing the size of the Union's crew up to seventy-four, of whom probably no more than sixty were seafarers. Of this number, twenty-eight had died at sea. James Coggan, himself a former merchant captain, was struck by the small size of the crew, remarking that the Union was a vessel of 750 tons. A regular East Indiaman of the same size would have been manned by a crew of 90 to 100 men, mostly British sailors. ${ }^{21}$ In its assessment of Mir Jahan's testimony, the Committee of Shipping drew attention to the recent wreck of the Suffolk, grounded off Falmouth after her sails had been

19. William Docker to James Coggan, 24 March I 802, in East India Company, Third Report of the Special Committee (London, I802), p. I I4.

20. Here, "sepoys" refers not to Indian soldiers of the Company's army, but to mercenaries privately hired to repel pirates, guard stores, and protect the ship's officers.

21. British Library, London, Oriental and India Office Collections, India Office Records, /H/sor, Home Miscellaneous Series [hereafter, HMS], fos 5-I I, Testimony of Mir Jahan, Serang of the Union. 


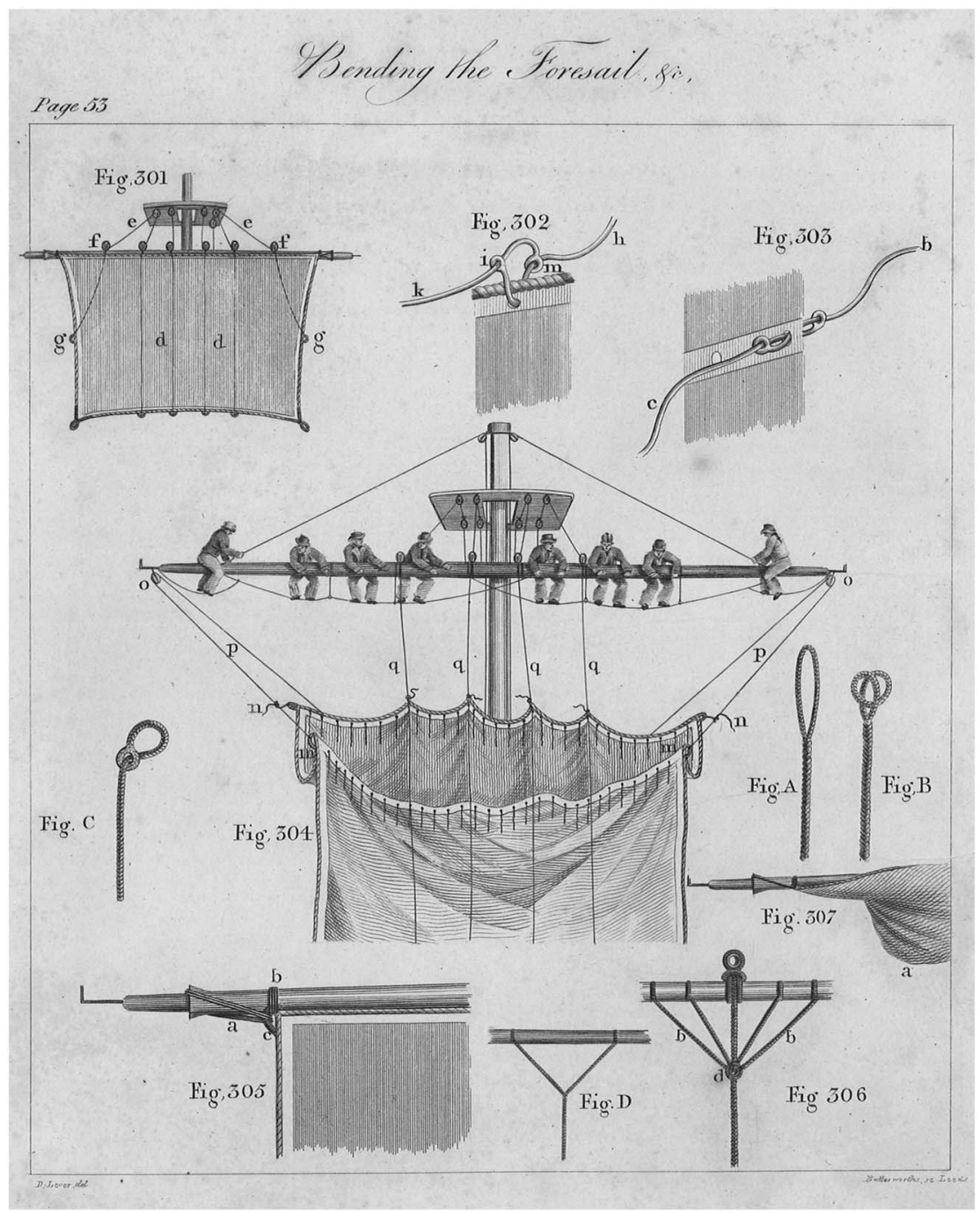

Figure I. An example of the labour-intensive and dangerous working of a square-rigged ship which might also indicate why the persistent undermanning of country trade vessels was so dangerous. From: Darcy Lever, The Young Sea Officer's Sheet Anchor, or Key to the Leading of Rigging and to Practical Seamanship, 2nd edn (London, I819), p. 53. Maritime Museum Rotterdam.

blown away during a storm. This accident, attributed to the small size of the Suffolk's crew, resulted in the death of a lascar trapped below decks. ${ }^{22}$

22. Ibid. For the wreck of the Suffolk (25 February 1802), see "Lloyd's Marine List", Caledonian Mercury, 6 March I 802. 
In early October I80I, anticipating peace with France, the Company forbade bringing "Chinese, Lascars, or other natives of India" home as part of a ship's crew, "except in cases of absolute and unavoidable necessity". Due to the war with France, restrictions on lascar crews had been relaxed since 1793 , especially for country ships, and the number of Indian mariners reaching London had increased six-fold. However, as Bell's Weekly Messenger smugly reminded readers, "[i]t has been ascertained that the labour of two Europeans is fully equal to the activity of three natives of India”. ${ }^{23}$ If lascars truly were unequal to English sailors, why were country ships with primarily lascar crews consistently undermanned?

In I 802, the average lascar earned about one-third less than a British sailor. For captains and shipowners, Indian sailors were cheap labour, especially as their provisions cost half as much as those provided to European mariners. ${ }^{24}$ However, the East India Company - required by law to look after lascars arriving in Britain, even those not aboard Maritime Service vessels - charged captains $\mathfrak{E}_{\mathrm{I}} 4$ for the maintenance and eventual repatriation of each lascar delivered to its depot, adding significantly to the cost of hiring lascars. The Union incident reveals that many captains and owners of country ships pretended to be unaware of this requirement. Indeed, if we believe Luke's account, neither he nor the Palmer brothers, who had been involved in shipping for years, had ever heard of the Company's lascar depot in Shadwell. ${ }^{25}$

The most revealing statement in Luke's defence of his management of the Union is his remark that "I thought it an unnecessary expense to carry a Surgeon on board [...] when I had determined to remove every sick Person to Shore". ${ }^{26}$ The memoirs of Robert Eastwick, another country ship captain, inform us that at the time of the Union events the country trade was a high-stakes, get-rich-quick business in which investors expected enormous profits from a single voyage, and accepted serious risks to life and property in order to maximize the return on their investment. ${ }^{27}$ H.M. Elmore, writing around 1800 , estimated that a rice ship making four runs annually across the Bay of Bengal could clear a profit of $£_{9,500}$ after paying operating costs of Rs 2,000 a month. ${ }^{28}$ Risk-taking and

23. "East India”, Bell's Weekly Messenger, 4 October i 80I, pp. 318-319.

24. Myers, "The Black Poor of London", pp. 7-2 I.

25. HMS, fos I-s, Capt. John Luke to James Coggan, 6 April I 802; ibid., fos 22-26, Nathaniel Dowrick to James Coggan, 8 April i 802.

26. Ibid., fos I-5, Capt. John Luke to James Coggan, 6 April I 802. Luke’s voyage from Bengal to London was virtually non-stop, with only a brief pause at St Helena.

27. Robert William Eastwick, A Master Mariner: Being the Life and Adventures of Captain Robert William Eastwick, ed. by Herbert Compton (London, I891), pp. 95, 252.

28. H.M. Elmore, The British Mariner's Directory and Guide to the Trade and Navigation of the Indian and China Seas (London, I802), p. 291. 
cost-cutting permeated the country trade, extending to crew management. At a time when water and provisions for one British seaman aboard an East Indiaman took up nearly a ton of cargo space, lascar provisions were cheaper and less bulky. Moreover, as Mir Jahan informed the Committee of Shipping, the Union's lascars were berthed "under the forecastle", exposing them to the elements, but freeing the lower-deck steerage for the stowage of extra cargo. ${ }^{29}$

In the age of sail, ships spent as long in port as they did at sea. In Asia, in particular, few ports had facilities for dockside loading and unloading. Weeks were needed to take on cargo and find a replacement crew. To trim costs, all non-essential crew were discharged from country ships, especially at Calcutta, where the interval between voyages was rarely less than six weeks. ${ }^{30}$ Ghat-serangs knew European captains had to sail with the trade winds or risk a long, expensive delay due to the change of the monsoon. The commanders' urgency, of course, intensified competition for crews, especially in the I780s and I790s, when the number of country ships at Calcutta increased in both number and size. In 1783 , the Government of Bengal, at the behest of country traders, had attempted to break the ghat-serang system by introducing a Marine Register Office, but the labour contractors had foiled this reform, supporting a general strike of lascars. European traders and captains continued to haggle with the ghat-serangs about the number and quality of the lascars they provided, demanding lower wages. Lascars, for their part, demanded larger advances, only to be accused of wanting to desert as soon as they were paid. After 1798, the struggle became desperate, with lascars accusing European captains of kidnapping stevedores, while Europeans believed every conflagration aboard a country ship was a ploy by lascars to abscond in the ensuing confusion. ${ }^{3 \mathrm{I}}$

Mindful of the need to control costs, satisfy investors, and maintain reputations, country trade captains routinely put to sea with inadequate crews. However, whether undermanning was a cost-cutting measure or an expedient employed to gain a competitive edge in negotiations with ghat-serangs, it was always dangerous. In 1793, for instance, Robert Eastwick nearly died when the Pesoutan, an undermanned 450-ton ship on which he served as first mate, foundered in a storm off Burma. More than two-thirds of the crew, including the captain, and all of the ship's passengers drowned, while the ship itself was completely destroyed - a

29. HMS, fos 5-I I, Testimony of Mir Jahan.

30. Elmore, The British Mariner's Directory and Guide, pp. 288-289.

31. Michael H. Fisher, "Finding Lascar 'Wilful Incendiarism': British Ship-Burning Panic and Indian Maritime Labour in the Indian Ocean", South Asia: Journal of South Asian Studies, 35 (2012), pp. 596-623; Jean Sutton, The East India Company's Maritime Service, 1746-I834 (Woodbridge, 2010), pp. 237-238; Elmore, The British Mariner's Directory and Guide, p. 288. 
disaster that might have been avoided if the lascar crew had not been overextended and exhausted. ${ }^{32}$

The navigation of a three-masted sailing ship was a quest for balance. A ship's hull and everything in it was designed or stowed to return the vessel to an upright position. However, this steadiness also depended on the management of yards and sails, which provided both wind-driven propulsion and resistance, the latter being necessary to slow or halt the ship. Sails were the chief steering mechanism of a ship, wheels and rudders being used only for making minor adjustments. Depending on the manoeuvre, sails had to be raised and lowered, and yards braced about simultaneously, or in carefully timed succession, to avoid mishaps. The proper handling of yards and sails required a team of men aloft and on deck for each mast, with another team at the helm, all directed by competent officers and petty officers.

To sail a 450-800 ton ship safely, at least 30 men were needed at all times. Since (presumably) those men had to eat and sleep eventually, during a long voyage, a minimum of sixty sailors were needed to sail any distance, thus enabling a captain to form two watches. However, even this level of staffing left no margin for attrition, which is why regular East Indiamen carried enough men to provide three watches, several replacements, and a dozen officers and petty officers. Aboard undermanned ships, the watch system could not be maintained: this meant the men received no proper rest. Under such circumstances, when subject to prolonged stress, a crew's physical stamina, mental focus, and morale could degrade quickly, mistakes might be made, and these errors imperil sailors' lives and their ship. Unfortunately, in the sailing ship's struggle for balance, in the face of natural forces as swift and powerful as wind and sea, a moment's success or failure could mean life or death. Thus, as manuals of the time pointed out already, captains venturing out to sea in undermanned ships gambled with their men's lives. ${ }^{33}$

The loss of the Pesoutan illustrates the problem. When Captain Newton acquired the vessel, Eastwick recalled, the American-built bark was "a rotten craft, $[\ldots]$ in such bad and crazy condition, [...] we were delayed a month patching her up to cross the Bay [of Bengal]". Still, Newton and his partner, a Parsi speculator named Dorabjee Byramjee, tried to wring as much profit from the used-up vessel as possible. In August 1793, after loading timber at Rangoon, Newton set sail for Madras with a crew of approximately thirty lascars, several European officers and petty officers, and at least thirty-one passengers. Sailing at the height of the south-west

32. Eastwick, A Master Mariner, pp. 68-75.

33. Richard Hall Gower, A Treatise on the Theory and Practice of Seamanship by an Officer in the Service of the India Company, 3 rd edn (London, I808). 
monsoon, they encountered a cyclone that battered the vessel for four days, bearing it back toward the Burmese coast. Heavily loaded, the ship wallowed, filling quickly after springing a leak. With only thirty men, all suffering from exposure and fatigue, Newton could neither manage the sails nor operate the pumps. He ordered Eastwick to cut away the masts, leaving the stump of the foremast, but this merely bought the crew a little time before, perhaps inevitably, the Pesoutan was overwhelmed. While the dilapidated condition of the vessel and the manner of its lading contributed to its loss, its undermanning could not be overlooked. ${ }^{34}$

\section{BRUTALITY AND RESISTANCE ABOARD THE UNION}

The connections between undermanning, deteriorating working conditions, and morale, discipline, and health are discernible in the testimonies of Union crewmen who complained about the misconduct of Captain Luke and his officers. Now, we will examine some of the evidence offered by those who sailed aboard the ill-fated ship, both British sailors and lascars. Most of these statements were offered and recorded at the Shadwell magistrate's office, near the lascars' depot, in April and June I 802.

According to Mir Jahan, "no sooner had the ship left Bengal River than the Mates began to flog the men till they fell sick, and while in that situation they continued to exercise the same discipline until they became totally unable to move". ${ }^{35}$ John Thomas, an Indian Christian seacunny, said, "I never beheld such cruelties [...] tho' I have sailed in two East India ships before, Henry Addington and the Coverdale". Significantly, Thomas contrasts his experiences aboard the Union with his treatment aboard two regular East Indiamen, suggesting that Company ships were better-managed. Like Mir Jahan, he also noticed officers flogging men as soon as the voyage began, leading immediately to the deterioration of their health, whereupon the lascars continued to be beaten for not working. This brutality, Thomas asserts, caused almost all the deaths aboard the ship. ${ }^{36}$ Peter Bill, the captain's steward, also reported that mariners who left Bengal in good health sickened due to the savage discipline imposed by the ship's officers, adding, "I never beheld the like before, tho' I have been two voyages to England in Country Ships". ${ }^{37}$

Mir Jahan noticed that men soon were sneaking below to hide, trying to obtain a little rest and avoid being beaten. Responsible for discipline, the serang himself was struck two dozen times for allowing lascars to shirk their duties. Eventually, some men injured themselves hoping for a

34. Eastwick, A Master Mariner, pp. 68-69.

35. HMS, fos I 5-17, Testimony of Mir Jahan, i6 April i 802 .

36. Ibid., fos 17-19, Testimony of John Thomas, Seacunny of the Union, 26 April I 802.

37. Ibid., fos I9-2 I, Testimony of Peter Bill, Captain's Steward of the Union, 26 April I 802. 
respite. However, the Union's mates offered these lascars no medical treatment. Fit or ill, every lascar was required to remain on deck. ${ }^{8}$ Peter Bill described how exposed the forecastle was to the elements, referring to it as perpetually wet. As the ship slowly approached the Cape of Good Hope, the lascars continued to be beaten despite "doing all they could". ${ }^{39}$ A lascar named Abraham testified that he was beaten for falling asleep on duty in the main-top, while everyone round him suffered so much from poor rations they became feverish, with swollen bodies and legs. Abraham also reported that the men had neither bunks nor hammocks, merely "Bengal blankets", being forced to sleep on deck, splashed by water in rough weather. ${ }^{40}$

Most atrocities committed aboard the Union were attributed to the Chief Mate, Samuel Plumb. However, Captain Luke was said to have encouraged Plumb's behaviour, and his violent treatment of the men required the commander's complicity. As the serang stated, "the Captain Ordered the Chief Mate to flog the Men [...] till he should see their back bones". ${ }^{\mathrm{I}}$ John Thomas remembered Luke laughing, seeing the mates beat the lascars, telling them to use larger sticks. ${ }^{42}$ Peter Bill testified that Luke ordered the mates to punish the lascars for complaining about their rations, remarking that he himself was struck by the captain when two chickens died in the coops off the Cape of Good Hope. ${ }^{43}$

Also testifying to the cruel behaviour of the Union's officers was John Moore, a British boatswain who joined the ship at Saugor. We know nothing of Moore's antecedents except that he had met one of the Union's lascars, Bakhshi, during a previous voyage aboard a different ship. Moore's experience aboard the Union offers insight into how the ship was managed. First, Moore was promised an advance of two months' pay, which he could not collect because the Chief Mate did not trust him to return to the ship from the agency house in Calcutta, where the money was held. Second, Moore was expected to participate in the mistreatment of the ship's crew, and help the officers conceal evidence of their assaults, which became necessary when lascars began to die. Moore, however, refused to be a party to these atrocities. As a result, he found his livelihood and his life in peril. Yet, instead of being a passive victim, Moore fought back, trying to organize both the ship's lascars and his fellow

38. Ibid., fos 5-I I, I 5-I7, Testimony of Mir Jahan.

39. Ibid., fos 19-21, Testimony of Peter Bill.

40. Ibid., fos 69-73, Testimony of Abraham, Sailor, 24 June I 802.

41. Ibid., fos 5-I I, Testimony of Mir Jahan.

42. Ibid., fos 17-19, Testimony of John Thomas, 26 April i 802.

43. Ibid., fos I9-2 I, 53-56, Testimony of Peter Bill, 26 April I 802 . Chicken coops were usually located on the poop deck, and chickens often died from exposure in rough weather. As steward, Bill was apparently also poulterer. 
European seamen to resist their tyrannical officers. However, he did not advocate mutiny. ${ }^{44}$

Even before the Union set sail, Plumb had marked Moore as a troublemaker, employing accusations, threats, and physical attacks to reduce the new boatswain to compliance with his draconian style of discipline. With Captain Luke present, Moore was told he would be demoted to a mere "hand" before reaching England. His rations were withheld for three days, to break his will, and Plumb blamed him for all manner of infractions as a pretext for resorting to violence. Moore recalled being seized by Plumb, who "shook me against the ship's side till the Blood gushed out of my mouth and eyes [...] saying he would not strike me for fear of the law, but that he would shake me to pieces". ${ }^{45}$ Significantly, this statement indicates that Plumb knew what the regulations protecting merchant seamen were, but had found or been shown ways to circumvent them.

Later, off the Cape of Good Hope, as the crew was setting a lower studding-sail, Plumb ordered Mir Jahan to beat the first tindal with a rope for taking too long roving the inner halyards. Moore, also ordered to beat the tindal, objected, arguing that the tindal "was an Officer of the Ship, as well as myself". This retort - recognizing the equality of a lascar, at least in Moore's mind - was intolerable to Plumb, who "threatened to throw me overboard", the boatswain testified, "if I did not obey his orders, be whatever they would". Seizing a rope, Plumb beat the tindal himself, leaving the man "for some time in a bruised state". ${ }^{46}$

The centrepiece of Moore's testimony, however, was his description of the fate of a tindal named Balla, injured so severely by Plumb he was no longer able to stand. Falling into despair, Balla told his shipmates he would not recover, and died, as Moore recalled, four days before the Union reached St Helena. According to John Thomas, the Chief Mate also beat another man, Bakhshi, so severely he, too, died within two or three days of being assaulted. ${ }^{47}$

At St Helena, the governor, Francis Robson, received a letter allegedly written by two of the Union's European sailors, Thomas Harrison and Thomas Taylor. "I am sorry to trouble you", the document began, "but the usage on board the ship has been so bad that I hope your goodness will order it to be looked into, there has been two Men murdered, one thrown overboard, the other beat so as to survive but two days after". ${ }^{8}$

44. Ibid., fos I0-15, Testimony of John Moore, 24 April 1802.

45. Ibid.

46. Ibid.

47. Ibid., fos 17-19, Testimony of John Thomas.

48. Ibid., fos 39-40, Thomas Harrison and Thomas Taylor to the Governor of St Helena, 4 January i 802 . 
Robson convened a court of enquiry consisting of the commanders of five East Indiamen which happened to be present in the anchorage, as well as Captain Brown of the country ship Ganges. ${ }^{49}$ When called before the court, however, Harrison denied any connection with the letter, saying it had been written by Moore. Nevertheless, he told the assembled captains that a lascar "on the point of death" was placed in the Union's fore-chains, and must have been heaved overboard after dying there. ${ }^{\circ 0}$ Taylor said the serang had thrown a dead lascar into the sea, adding that this was the usual, unceremonious way of burying such men. ${ }^{5 \mathrm{I}}$

Moore admitted to writing the letter to Governor Robson and signing Harrison's name to it. He also said he had not seen the serang pitch anyone overboard, but had heard about it from Harrison and a lascar named Jamal..$^{52}$ Jamal himself stated that an injured lascar, in a state of putrefaction, had been lashed into the fore-chains, being deemed a health risk. When he disappeared, all presumed he had been cut down and buried at sea by the serang. However, Jamal denied ever speaking to Moore, telling the court Moore had told him to say the lascar in the fore-chains had been thrown overboard. ${ }^{53}$

When questioned about the fatal beating of Bakhshi, the witnesses gave conflicting testimony. Harrison claimed to know nothing while Taylor said he saw Plumb knock the man down with a rope as he himself manned the wheel, although he later changed his story, remarking that Bakhshi merely became sick and died. Moore's story, meanwhile, was more elaborate. Plumb had ordered him to search below for a lascar who had quit the deck, and not to bring him back, but to "correct him" out of sight. Instead, aided by a tindal, Moore located the man and brought him topside, where the tindal and a sepoy "kick'd and beat the said Lascar so that he died three days after". Under cross-examination, however, Moore altered his account, stating that Plumb himself beat the lascar, who died fifteen days later. ${ }^{54}$

Unfortunately for Moore, Jamal denied Plumb ever beat the lascars "to do them injury". He contradicted Moore's revised statement, reminding the court the boatswain had told him what to say, before adding that Moore was plotting mutiny. 55 The Court of Enquiry instantly dismissed

49. Ibid., fo. 39. The Maritime Service officers present were Richardson, Rymer, Eilbuk, Lamb, and Todd.

50. Ibid., fos 40-4I, Testimony of Thomas Harrison, St Helena, 5 January I 802.

s. Ibid., fo. 4I, Testimony of Thomas Taylor, St Helena, s January i 802.

52. Ibid., fo. 4I, Testimony of John Moore, St Helena, 5 January I 802.

53. Ibid., fo. 42, Testimony of Jamal, Lascar, St Helena, 5 January i 802.

54. Ibid., fos 43-44, Testimonies of Thomas Harrison, Thomas Taylor, and John Moore, St Helena, 5 January i 802 .

55. Ibid., fo. 44, Testimony of Jamal, Lascar. It must be noted that Jamal's testimony was given via a translator. In Hindustani, the words typically translated as "mutiny" in English are more suggestive of being faithless or fractious. 
the charges against the Union's officers, describing them as "injurious, malicious [...] false accusations". Moore, meanwhile, was recorded as being of "mutinous and disaffected disposition". ${ }^{56}$ As the court adjourned, the captains converged on Moore, one allegedly saying the boatswain should have been placed in the fore-chains, while another remarked that Moore ought to be hanged for accusing superiors of misconduct. Meanwhile, Captain Brown, of the country ship Ganges, merely suggested that lashing the rotting lascar into the fore-chains might have been for the best. ${ }^{57}$

In the aftermath of the court of enquiry at St Helena, Moore was demoted. However, as Moore later confessed to the Committee of Shipping, both Plumb and Luke suggested the former boatswain ought to help conceal what had happened aboard the Union. ${ }^{58}$ Moore's shipmates avoided him after the enquiry at St Helena, but he persevered, despite continual harassment by Plumb. By the time the Union reached the Thames, the situation aboard the ship had deteriorated even further. More than two dozen men had died, and most of the crew was ready, finally, to rally behind Moore. As the Committee of Shipping reported, in addition to Mir Jahan, seven other lascars, sailors, and servants were clamouring to tell their stories. ${ }^{59}$ Only one witness, a passenger aboard the Union, testified on Luke's behalf, informing the Company that the vessel's commander was "a remarkably mild tempered Man", adding that he had never seen Luke harm anyone, although Plumb he described as "a man of irritable temper", acknowledging that the Chief Mate beat the lascars with a rattan, although not "too severely". ${ }^{\circ}$

\section{THE LIMITS OF LASCARS' LEGAL PROTECTION}

Henry Smith, the East India Company's counsel, analysed the testimony provided to the Committee of Shipping on 27 June I 802, and was inclined to believe Moore and the lascar witnesses precisely because their stories were confused regarding details and dates.

There are certainly $[\ldots]$ material contradictions in the Evidence which make it necessary to weigh it with jealousy, but not withstanding such contradictions, I am convinced the whole of it is not founded in fiction, more especially as many of the apparent contradictions [...] arise from the difficulty of making illiterate persons attend to the distinction of what they know of their own knowledge

56. Ibid., fos 42-43, 45, Findings of a Court of Enquiry, St Helena, 5 January 1802.

57. Ibid., fos $73-83$, Testimony of John Moore before the Committee of Shipping.

58. Ibid.

59. Ibid., fos 5-I I, The Committee of Shipping's evaluation of the Testimony of Mir Jahan.

6o. Ibid., fos 87-89, Testimony of Captain Wright, Passenger aboard the Union. The other two passengers, a Lieutenant Murray and a Mrs Smith, could not be located by the Committee. 
and what they have heard, and also from their imperfect acquaintance with our language and the imperfect manner in which their testimony can be taken by an interpreter. $^{6 \mathrm{I}}$

Seeking to corroborate some of the testimony they had heard, the Committee demanded Luke's logbook, which remains in the India Office archive to this day. Unlike the detailed log of a regular East Indiaman, Luke's journal was a vague record of navigational data - typical of the logs of private merchantmen. The only punishments recorded were those meted out to Thomas Harrison and George Andrews for theft, on ro November I 80 I. Lascars' deaths were recorded, as they occurred, but no cause of death was ever mentioned. ${ }^{62}$

Aboard the Union, the distinction between formal, severe punishment (flogging) and "starting" (being struck with a rope) dissolved completely. The Chief Mate and other European officers resorted to corporal punishment to compel lascars to work beyond the normal limits of endurance - a desperate measure necessitated by undermanning the ship in the first place. Plumb emerges from the crews' testimonies as a violent sociopath, but the attitude of Captain Luke deserves close attention. The Union was not the only country ship arriving in London in 1802 with an incapacitated crew. Luke also was not the only commander feigning ignorance, using misleading arguments, and refusing to cooperate properly with the Committee of Shipping's investigation. Clearly, there was a pattern of brutality and obfuscation in the management of privately owned country ships.

Henry Smith noted, in his report, that the Union's charter-party included three instructions. First, the vessel, being so large, was to be provided with a European or Indian "medical person", which presumes that the ship also was to be adequately manned. Second, the crew was to have "healthy and roomy births [sic] and lodging places". Third, the ship was to be inspected by the Master-Attendant at Saugor prior to departure. ${ }^{63}$ As we have seen, during the Union's voyage, the crew had neither medical care nor proper accommodation. However, for the sake of appearances, they might have slept below decks until the MasterAttendant had completed his inspection.

Smith's assessment of the evidence gathered during the Committee's investigation was that Plumb, although probably guilty of criminal assault, most likely would not be convicted of murder. In any event, by the time Smith drafted his report, Plumb had shipped out for India aboard

6r. Ibid., fos 95-123, Results of the Investigation into the Management of the Union and Perseverance.

62. British Library, London, Oriental and India Office Collections, India Office Records, L/MAR/B/i I7C, Logbook of the Union, Captain John Luke, 23 June i 80 I to 2 April i 802. 63. HMS fos $95-\mathrm{I} 23$, Results of the Investigation. 
another ship. Smith reckoned the Supreme Court of Bengal might prosecute Plumb, but there was little chance of organizing a trial with the witnesses so widely scattered. ${ }^{64}$ Apparently, a warrant was issued for the apprehension of Captain Luke, but he, too, evaded the law, leaving the country at the first opportunity. ${ }^{65}$

William Adam, a barrister of Lincoln's Inn, also studied the Union case. $\mathrm{He}$, too, felt that the testimony of Moore and the lascars was authentic, its inconsistencies proof they had not entered into a conspiracy. However, Adam believed only the testimony of a ship's surgeon could legally establish the cause of death of the lascars aboard the Union. Plumb might be convicted of a misdemeanour, but was unlikely to be found guilty of murder. In addition, it was uncertain, in I 802, whether Act 39, Geo. 3, ch. 37 (The Offences at Sea Act of 1799) permitted Indian courts to try cases involving misdemeanours at sea. Thus, Plumb could not be tried unless he returned to England. However, the crucial detail, for Adam, was the clearance of the Union by the Company's Master-Attendant at Calcutta. This official's stamp of approval provided Luke with a strong alibi. In the end, the only charge that could be laid at Luke's door was a mere violation of the charter-party owing to his failure to hire a surgeon. ${ }^{66}$

The system of lascar employment, designed to keep wages low and Indian sailors subservient, was in part the product of lascar acquiescence. However, as Mir Jahan told the Committee of Shipping, the Union's crew eventually resisted en masse. After leaving St Helena, the crew practiced passive resistance, avoiding duty in various ways. ${ }^{67}$ The fact that so many witnesses contrasted their experience aboard the Union with what they had seen on other ships indicates they did not consider how they were treated to be normal. Significantly, Peter Bill recalled how, en route from St Helena to England, the crew "remonstrated" with the officers regarding the treatment of the sick, whereupon the steward finally was allowed to provide men who were ill with some relief, although by then it was too late. ${ }^{68}$

The Union's owners distanced themselves from the vessel's officers, who in turn tried to misdirect the Company's investigation. Ultimately, the Committee of Shipping did not prosecute the ship's officers, for practical reasons, but at the height of the Union inquiry the Company's will to secure justice was strong. Policy considerations overrode humanitarian concerns only when legal experts indicated the technical problems preventing successful prosecution of those responsible for the Union events.

66. Ibid., fos I27-I 34, Analysis of William Adam, 8 July I 802 .

67. Ibid., fos I 5-17, Testimony of Mir Jahan.

68. Ibid., fos I9-2 I, Testimony of Peter Bill. 
We cannot attribute the decision not to prosecute to simple greed or racism, for other factors were taken into consideration, in particular practical legal problems concerning physical evidence and the possibility of obtaining convictions. Although they risked everything, even death especially on the open sea - the Union's crew made an impression on Company officials, reflected in later legislation. In future, captains were required to explain, in writing, why "missing" lascars had died at sea, and lascars' work, under the East India Company's aegis, became safer - at least theoretically. ${ }^{69}$ In reality, since expedience always seemed to trump good intentions, lascar working conditions may have become worse, by the end of the Napoleonic Wars, than they were during the sailing season of $\mathrm{I} 80 \mathrm{I}-\mathrm{I} 802$.

Rather than focusing on their sadism, it is more useful to consider how Luke and Plumb employed violence to terrorize lascars as part of a system of labour management that included systematic, deliberate elimination of the evidence of brutality. Luke apparently understood that the weight of official documents was on his side, while the finding of the St Helena court of enquiry was probably a foregone conclusion. Few commanders of East Indiamen, at that time, would ever question a captain's absolute authority aboard his own vessel. In the face of such suppression and managerial control of information, it is remarkable that the story of the Union's lascars was ever told at all.

\section{CONCLUSION - THE UNION'S HISTORICAL SIGNIFICANCE}

Fourteen years before the East India Company's counsel warned the Committee of Shipping that prosecuting Luke and Plumb would be impossible, anti-slavery activist Thomas Clarkson had noted that the conditions of a mariner's life generally denied him legal protection. Sailors engaged in long-distance trade were transients, without connections or resources, living in taverns while looking for work. Usually, it was impossible to find witnesses to corroborate a sailor's evidence, while the accused often left the country before they could be charged or prosecuted. In cities dependent on maritime trade, magistrates were usually local merchants who identified with ships' officers as fellow gentlemen. Magistrates and jurors viewed working-class plaintiffs as insubordinate employees rebelling against authority. Thus, Clarkson concluded, sailors faced nearly insurmountable obstacles in seeking redress for grievances. ${ }^{70}$

69. East India Company, The Law Relating to India and the East-India Company (2nd edn, London, I $84 \mathrm{I}$ ), p. 247.

70. Thomas Clarkson, The Grievances of Our Mercantile Seamen: A National and Crying Evil (London, I845), pp. I3-17. 
Clarkson's interviews with some sixty-three sailors, survivors of the Atlantic slave trade, garnered a wealth of information concerning the brutality of the Middle Passage, including the revelation that slave-trade sailors were systematically exploited and subjected to violent coercion. The narratives of shipboard labour practices gathered by Clarkson are identical, in nearly every detail, to the stories told by John Moore and the Union's lascars. Aboard slave ships, mariners were denied proper berths and medical care; they were kept constantly at work, harassed and threatened, beaten with handspikes, kicked when ill, given insufficient rations and water, and lashed to the shrouds if they claimed they were too injured or sick to work. Slave-trade veterans told Clarkson how men were driven to suicide, and others killed or maimed by officers concerned only with exerting authority, maximizing profits, and avoiding prosecution. One after another, Clarkson's informants described the "common system" of the "Guinea trade", consciously designed to wear men down, killing them or compelling them to desert their ships out of fear before they could be paid in full. In the West Indies, discarded and unwanted, diseased and injured English sailors literally piled up on the docks, forming communities of destitute whites in the plantation colonies, whose only friends, often, were the very slaves they had delivered into bondage. Reading Clarkson's report it becomes clear that, in fact, the situation of abandoned mariners in the West Indies was quite comparable to that of the lascars accumulating in London, to subsist as the objects of charity, unable to obtain passage home. ${ }^{\text {I }}$

There may be a connection between the specific brutality experienced aboard the Union and the institutionalized violence of the slave trade. We know little about Captain John Luke, but he may have been an American forced into the east India trade by the suppression of the slave trade and the wartime decline of trade with Europe. At least one American captain, Benjamin Stout of the country ship Hercules, shipped rice for the East India Company around the same time. ${ }^{72}$ In I 802 , Luke addressed his letters from the Virginia Coffee House, described in a contemporary guidebook as being "frequented by merchants [...] trading to those parts". Two other inns, within a few hundred feet of the Virginia, also specialized in entertaining officers involved in trade with the West Indies and Africa. ${ }^{73}$ Because he resided in a tavern after a voyage from India, and not at home, Luke probably was not any of the men of the same name and social class known to have lived in England at the time. ${ }^{74}$ However, he

71. Idem, The Substance of the Evidence of Sundry Persons on the Slave-Trade, Collected in the Course of a Tour Made in the Autumn of the Year 1788 (London, I789).

72. James Lindridge (ed.), Tales of Shipwrecks and Adventures at Sea (London, I846), pp. 202-203.

73. John Feltham, The Picture of London, for I 805 (London, i 805 ), p. 35 I.

74. The names and locations of all qualified electors are found in Great Britain, Parliament, History of the Proceedings and Debates of the House of Commons (London, I802). 
may be the John Luke mentioned in a Connecticut court case of 1796 as residing in Demarara, in Dutch Guiana, and named as co-executor of an estate. ${ }^{75}$ It is impossible to say whether Luke and Plumb were former slavers, but comparison of the Company's documentation of the Union atrocities with the testimonies collected by Clarkson reveals that these men managed their ship exactly like a slaving vessel.

Violence played a part in labour-management interactions aboard almost all ships involved in long-distance trade during the age of sail, especially those employing contract labourers. Lascars, furthermore, were not the only contract labourers in maritime transport at this time. English sailors in the slave trade were often compelled to go aboard slavers by crimps, who colluded with ship owners and captains to swindle the men out of their pay. ${ }^{76}$ In American whaling ports, contractors operating much like India's ghat-serangs helped "green" men and foreigners find ships, plunging would-be sailors into debt with heavy outfitting expenses and the cost of advances against meagre wages. ${ }^{77}$ African-American sailors, representing 18 per cent of America's maritime labour force by I803, found that their equal pay and integration into white crews frequently provoked violent backlashes, without breaking the racial barriers that prevented most black mariners from becoming officers even after decades of service. ${ }^{78}$ Whaling voyages, lasting three to five years, taking ships to remote regions, were especially dangerous for both officers and men, as attested by the I 845 voyage of the Archer. Captain Moses Snell's carefully worded logbook, parts of which were fraudulently composed to conceal his violence, nevertheless could not hide the fact that his own brother led a mutiny against him. ${ }^{79}$ In the South Pacific, meanwhile, Polynesian chieftains served as labour contractors, placing their countrymen aboard ships as maritime workers in exchange for trading privileges. Pacific islanders toiling aboard sandalwood-traders and whaling ships also endured the same violence meted out to lascars and European seamen, in addition to being cheated out of their pay and abandoned in foreign ports. The flogging of a Maori sailor, a chief's son, was one of the causes of the "Boyd Massacre" of December i 809, at Whangaroa in New Zealand. ${ }^{8 \circ}$

75. Jesse Root (ed.), Reports of Cases Adjudged in the Superior Court and in the Supreme Court of Errors in the State of Connecticut, vol. II (Hartford, CT, 1802), p. 364.

76. Clarkson, Substance of the Evidence of Sundry Persons, p. 16.

77. Kathryn Grover, The Fugitive's Gibraltar: Escaping Slaves and Abolitionism in New Bedford, Massachusetts (Boston, MA, 2009), p. 7.

78. W. Jeffrey Bolster, Black Jacks: African American Seamen in the Age of Sail (Cambridge, MA, 2009), pp. 2-6.

79. James C. Johnston, The Yankee Fleet: Maritime New England in the Age of Sail (Charleston, SC, 2007), pp. I I4-I I6.

80. Robert McNab (ed.), Historical Records of New Zealand, vol. I (Wellington, I908), pp. 306-308. 
In branches of commerce in which contract labourers were rare, such as the California hide trade of the I830s, violence was still part of maritime life, as attested by Richard Henry Dana in his first-hand account of an ordinary sailor's life, Two Years Before the Mast, recording his voyage aboard the American trading vessel Pilgrim in i834-1836. Dana, a Harvard undergraduate who went to sea to recover his health, clearly and thoroughly analyses the working environment on board an isolated vessel at sea. Dana explains the intricate power dynamic, based on scripted, hierarchical roles, linking the captain, first mate, and subordinate officers of a ship, as well as the subtle difference between the captain's servants and the ship's crew - all matters brought vividly to life in the records concerning the Union. ${ }^{8 \mathrm{I}}$

Dana likens the sailor aboard a ship to a prisoner, writing, "in no state prison are convicts more regularly set to work, and more closely watched". Subject to constant surveillance, sailors were forbidden to talk to each other and kept busy, as a matter of coercive policy, even when there was nothing to do. ${ }^{82}$ "Jack is a slave aboard ship", Dana remarks in another passage, "but still he has many opportunities of thwarting and balking his master". Working slowly, in a shoddy manner, was a common resistance tactic adopted by sailors, but aboard the Pilgrim this "balking" provoked a violent reaction from Captain Frank Thompson. ${ }^{83}$ Dana dramatically recounts how Thompson, desperate to retain control over his men, flogged two of them while yelling that by doing this he was making them "slaves", referring to himself as a "slave-driver". The racially charged perception of violence, even aboard the Pilgrim, with its mostly white crew, is impossible to ignore.

Dana makes it clear that Thompson employed violence not to punish men, but to degrade and "break" them, furthering his control over every aspect of their lives, taking advantage of their own prejudices. ${ }^{84}$ As for the first mate, he was not a man like Plumb, of the Union. Dana, significantly, describes the Pilgrim's mate as "too easy and amiable for the mate of a merchantman. He was not the man to call a sailor a 'son of a bitch,' and knock him down with a handspike". 85 Finally, Dana reminds us how overt resistance by sailors, at sea, was legally construed as mutiny, while seizing a ship, even for their own safety, was piracy. Well aware that the peculiar nature of their work prevented them from obtaining justice ashore, most sailors had little choice but to acquiesce. As for Dana, as

8I. Richard Henry Dana, Two Years before the Mast: A Personal Narrative of Life at Sea (Boston, MA, I869), pp. II-I 2.

82. Ibid., pp. I $5-17$.

83. Ibid., pp. $8 \mathrm{I}-82$.

84. Ibid., pp. I I3, I I6-I I7.

85. Ibid., pp. го3-го4. 
soon as Thompson realized he was educated and prepared to tell his companions' stories, he sent the young scholar home aboard another vessel, assuring he would arrive long after the Pilgrim, thus forestalling any legal proceedings. ${ }^{86}$ Also, Clarkson had found, in his study of the slave trade, that owners and captains used their control over maritime labour to eliminate potential witnesses by placing them aboard departing ships. ${ }^{87}$

Viewed in a broader context, the Union events appear as an extreme case of violence in labour-management relations in the maritime transport sector, although - as I have demonstrated - deliberate and systematic violence was an integral part of "efficiency" in the shipping industry, together with officers' efforts to hide brutal aspects of maritime life by self-editing documents. Aboard Company vessels, several officers kept separate journals, which were examined by the Committee of Shipping after each voyage, making this sort of subterfuge far less likely. Thus, in a study of official records and private memoirs concerning more than twenty voyages of regular East Indiamen during the period $1768-1826$, I have encountered nothing like the events aboard the Union, and few references to severe corporal punishment. Sailors aboard East Indiamen were well paid compared with seamen in other trades, and although lascars did not receive equal pay they were protected by enforced Company regulations and by the fact that regular East Indiamen carried numerous passengers, many of whom independently recorded events aboard these ships.

Most works on lascar history criticize the Maritime Service's treatment of lascars by emphasizing an uncharacteristic incident, the sinking of the Elizabeth, off Dunkirk, in $18 \mathrm{I} \circ$, in which 3 10 lascar passengers and 8 female servants being repatriated to India drowned after being driven from the lifeboats by European officers and passengers. It must be noted that the Elizabeth was not a regular Indiaman, but an "extra" ship, much like the Union. One of the only eyewitness accounts of the sinking we have was penned by country trade captain, Robert Eastwick, who disliked lascars. ${ }^{88}$

A much more accurate picture of the situation of lascars, however, can be gained when turning our attention away from regular East Indiamen and towards country ships. Aboard these, most sailors were lascars, yet they were considered incompetent and cowardly, hired only to reduce expenses, and because European mariners were scarce. John Hobart Caunter, a missionary sailing from Calcutta to Madras aboard a country ship manned by three European officers and forty lascars, noted how the Indian sailors fell into despair after encountering a gale, and how they

86. Ibid., p. I I4.

87. Clarkson, Grievances of Our Mercantile Seamen, p. I5.

88. Georgie Wemyss, The Invisible Empire: White Discourse, Tolerance and Belonging (London, 2012), p. I53. 
were compelled to work, being struck with the ends of ropes. ${ }^{89} \mathrm{~A}$ few years later, in November I 838, a British sailor voyaging from Moulmein to Madras aboard the country ship Tenasserim described the terror of the undermanned vessel's twenty lascars during a hurricane near the Andamans. Fleeing below decks, the men had to be "dragged from their hiding places and threatened with instant punishment". $9{ }^{\circ}$ One discerns in these anecdotes the everyday, humiliating maritime violence described by Dana, writing about the same period, but nothing like the atrocities committed aboard the Union, which were on a par with the worst outrages of the Atlantic slave trade.

89. John Hobart Caunter, The Oriental Annual, or Scenes in India (London, I836), pp. I-I 2. 90. Lindridge, Tales of Shipwrecks, pp. 278-279. 